\title{
PENGEMBANGAN MODUL PEMBELAJARAN KALKULUS 1 BERBASIS PROBLEM BASED LEARNING DI STMIK DUTA BANGSA
}

\author{
Anisatul Farida ${ }^{1}$, Ratna Puspita Indah ${ }^{2}$. \\ ${ }^{1}$ Teknik Informatika, STMIK Duta Bangsa \\ ${ }^{2}$ Sistem Informasi, STMIK Duta Bangsa \\ 'email: anisatul_farida@stmikdb.ac.id \\ email: ietha chu@yahoo.com
}

\begin{abstract}
The purpose of this research is to develop module Calculus 1 based the problem based learning that valid, practical, and effective in Calculus 1 at Information Enginering of STMIK Duta Bangsa. This research is development research using $4 D$ model. The steps are define, design, develop, and diseminate. The define steps are syllabus and textbook analysis, review of literature, and interview about lesson and college student about learning in the classroom. The design step is design of workbook. The develop steps are consists of validation, praktikalitas, and effectiveness. After designed, workbook will be validated by validator. At the praktikalitas step, workbook was tried out to students semester 1 of Information Enginering in STMIK Duta Bangsa. This event will be observed by an observer. The effectiveness of workbook observed at the same time with praktikalitas steps. The effect that observed were the activities and student learning outcomes. The technique of collecting data was done by validation sheet, observation sheet, field notes, and an interview. The data was analyzed by using of descriptive set. The disemination step was spread of the product. The outer of this research is prototype, model, module of Calculus 1 and national journal publication. The result showed that module of Calculus 1 having validity very valid by content and construk. According by observation and interviews note showed that module Calculus 1 was already practical and easy to used by students. Module of Calculus 1 is effective according to the study and observation activity students. This research was indicated that by using modules can improving activity and learning outcomes students.
\end{abstract}

Keywords: module, problem based learning, Kalkulus 1

\section{PENDAHULUAN}

Data BAK (Biro Administrasi Akademik) tahun pelajaran 2015/2016, nilai kalkulus 1 mahasiswa program studi Teknik Informatika di STMIK (Sekolah Tinggi Manajemen dan Ilmu Komputer) menunjukkan bahwa mahasiswa yang memperoleh nilai kurang dari 65 (kategori C, D, dan E) sebesar $59 \%$. Kenyataan ini masih jauh dari harapan. Proses perkuliahan Kalkulus 1 selama ini menggunakan metode ceramah dan menggunakan satu buku teks. Berdasarkan pengamatan peneliti, buku teks Kalkulus 1 yang dipakai oleh mahasiswa sulit untuk dipahami dan bahasa buku teks yang digunakan masih belum komunikatif dan interaktif. Inilah yang menyebabkan mahasiswa sulit memahami suatu materi dan tidak termotivasi untuk belajar mandiri. Mahasiswa tidak aktif dalam proses perkuliahan. Perkuliahan hanya bersifat satu arah. Dosen tidak lagi berfungsi sebagai fasilitator tetapi sudah beralih fungsi sebagai pentransfer seluruh ilmu yang dimiliki tanpa menyadari bahwa mahasiswa sudah mempunyai pengetahuan yang dimiliki sebelumnya.

Penggunaan metode ceramah juga mengakibatkan kemampuan berpikir kritis serta pemecahan masalah mahasiswa rendah Dimyati 
(2006). Salah satu model pembelajaran yang dapat membantu mahasiswa dalam meningkatkan kemampuan berpikir dan pemecahan masalah adalah pembelajaran berbasis masalah. Pembelajaran berbasis masalah merupakan salah satu model pembelajaran inovatif yang dapat memberikan kondisi belajar aktif kepada mahasiswa. Pembelajaran ini menekankan kepada proses penyelesaian masalah yang dihadapi secara ilmiah. Mahasiswa tidak hanya sekedar mencatat dan menghapal materi, namun mahasiswa aktif berpikir dan akhirnya dapat membuat kesimpulan. Kemandirian mahasiswa dapat diatasi dengan mengembangkan modul berbasis masalah sehingga materi mudah dipahami oleh mahasiswa secara mandiri tanpa mengharapkan seluruh materi ditransfer oleh dosen pengampu mata kuliah.

Menurut Rudi (2010: 5) sistem pembelajaran modul akan menjadikan pembelajaran lebih efisien, efektif dan relevan. Modul berbasis problem based learning ini berisi standar kompetensi, bahan diskusi, uraian materi, contoh soal, latihan, dan evaluasi tengah semester maupun akhir semester. Modul dibuat dengan menarik dan jelas dengan memberikan kasus sebagai bahan diskusi mahasiswa berbasis problem based learning agar mahasiswa termotivasi untuk belajar. Dengan modul ini, mahasiswa diharapkan akan mampu mendefinisikan masalah, kemudian merumuskan masalah, merumuskan hipotesis, mengumpulkan data, menguji hipotesis, dan menentukan pilihan penyelesaian. Modul berbasis masalah ini diharapkan juga dapat memotivasi mahasiswa belajar mandiri dan meningkatkan kemampuan pemecahan masalah pada mahasiswa. Modul berbasis problem based learning dapat dikatakan praktis dan efektif apabila mudah digunakan dari segi isi maupun waktu serta sudah sesuai dengan standar kompetensi yang harus dikuasai oleh mahasiswa.

\section{METODE PENELITIAN}

Jenis penelitian ini adalah penelitian dan pengembangan (Research and development $/ R \& D)$. Prosedur pengembangan modul ini menggunakan model 4-D yang dikemukakan oleh Thiagaragan dkk, dalam Trianto (2007:65). Model ini terdiri dari 4 tahap, yaitu tahap define, design, develop, dan disseminate. Pada tahap define yang dilakukan adalah analisis silabus dan buku teks, mereview literatur, serta wawancara teman sejawat mengenai materi ajar dan mahasiswa mengenai pembelajaran di dalam kelas. Pada tahap design dilakukan perancangan buku kerja. Tahap develop terdiri atas tahap validasi, praktikalitas, dan efektivitas. Setelah dirancang, buku kerja akan divalidasi oleh validator. Pada tahap praktikalitas, buku kerja diuji cobakan kepada mahasiswa Program Studi Teknik Informatika di STMIK Duta Bangsa semester 1. Kegiatan ini diamati oleh observer. Efektivitas buku kerja diamati bersamaan dengan tahap praktikalitas. 
Pengembangan Modul Pembelajaran Kalkulus 1 Berbasis Problem Based Learning Di STMIK Duta Bangsa

Anisatul Farida, M.Pd., Ratna Puspita Indah, S.Si., M.Pd

Efek yang diamati adalah aktivitas dan hasil belajar mahasiswa. Data dikumpulkan melalui lembar validasi, observasi, angket, dan wawancara, kemudian dianalisis secara deskriptif. Tahap diseminasi adalah tahap penyebaran produk.

Prosedur penelitian ini meliputi beberapa tahapan. Tahapan-tahapan tersebut yaitu, analisis kebutuhan, perancangan (penyusunan prototipe), pengembangan (validasi prototipe), implementasi (uji efektivitas dan praktikalitas produk), serta evaluasi dan revisi. (Lufri: 2008)

Instrumen yang digunakan dalam penelitian ini adalah lembar validasi, lembar observasi, angket, dan pedoman wawancara.

\section{HASIL DAN PEMBAHASAN}

Penelitian pengembangan ini menghasilkan produk berupa modul kalkulus 1 berbasis problem based learning. Modul ini berupaya untuk memfasilitasi proses belajar secara mandiri bagi mahasiswa. Setelah selesai proses perancangan, selanjutnya akan dilakukan uji validitas, praktikalitas dan efektifitas.

1. Validitas Modul Berbasis Problem Based

\section{Learning}

Kegiatan untuk mendapatkan modul PBL pada mata kuliah Kalkulus 1 diawali dengan tahap pendefinisian. Pada tahap ini dilakukan analisis terhadap silabus dan buku ajar. Hasil analisis diperoleh bahwa materi tersebut telah sesuai dengan kompetensi yang harus dicapai oleh mahasiswa. Setelah analisis, kegiatan selanjutnya adalah diskusi dengan teman sejawat. Berdasarkan analisis-analisis tersebut, maka dirancanglah modul berbasis masalah (problem based learning) untuk mata kuliah Kalkulus 1. Modul yang dirancang terdiri dari dua kegiatan belajar. Kegiatan belajar 1 untuk pokok bahasan limit dan kegiatan belajar 2 untuk pokok turunan. Modul diharapkan dapat membantu kemandirian mahasiswa dalam perkuliahan. Validitas yang dilakukan pada penelitian ini menekankan pada validitas isi dan konstruk. Hasil validasi oleh validator menunjukkan bahwa validitas modul kalkulus 1 berbasis problem based learning pada mahasiswa Program Studi Teknik Informatika STMIK Duta Bangsa memperoleh rata-rata skor validasi adalah 3,41. Dengan merujuk kepada kriteria, modul berbasis problem based learning dapat dikatakan valid dari segi isi dan konstruk.

Modul berbasis problem based learning yang valid dari segi isi berarti modul berbasis problem based learning yang telah dirancang sesuai dengan silabus mata kuliah, sedangkan valid dari segi konstruk berarti komponenkomponen modul berbasis problem based learning tersebut sesuai dengan indikatorindikator yang telah ditetapkan. Hal ini sesuai dengan penelitian Suprawoto (2009) bahwa bahan ajar berbentuk modul harus valid. Ini telah menjawab rumusan problem based learning "Bagaimana validitas modul berbasis 
problem based learning pada mata kuliah Kalkulus 1.

Penilaian validitas isi dan konstruk dapat disimpulkan sebagai berikut:

a. Rumusan standar kompetensi sudah jelas dan komprehensif serta jumlah standar kompetensi sesuai dengan waktu yang tersedia. Direktorat Pembinaan SMK dalam Husna (2013) menyatakan modul harus memuat tujuan pembelajaran yang jelas, dan dapat menggambarkan pencapaian standar kompetensi dan kompetensi dasar. Rumusan standar kompetensi yang jelas dan komprehensif membuat mahasiswa mengetahui tujuan yang diperoleh jika mengikuti perkuliahan Kalkulus 1. Waktu yang tersedia sesuai dengan standar kompetensi membuat mahasiswa dapat memahami materi perkuliahan dengan baik.

b. Modul memiliki ciri khas, mampu memotivasi, serta bermanfaat untuk mahasiswa. Modul untuk perkuliahan Kalkulus 1 memiliki ciri khas, yaitu modul yang dikembangkan berbasis problem based learning dengan menampilkan kasus di awal kegiatan. Selain bercirikan pembelajaran berbasis problem based learning, modul memuat contoh dengan dengan langkah yang rinci. Modul berbasis problem based learning bermanfaat untuk mahasiswa karena mampu memotivasi mahasiswa dalam perkuliahan. Hal ini sejalan dengan Muljono (2001:1) yang menyatakan modul dapat meningkatkan motivasi belajar mahasiswa.

c. Isi modul berupa teori dan soal yang dipakai sesuai dengan materi. Soal yang diberikan juga bervariasi yang bertujuan agar mahasiswa tidak mengalami kebosanan ketika mengerjakan soal. Soal yang diberikan juga sudah sesuai dengan silabus mata kuliah Kalkulus 1, sehingga kompetensi yang diharapkan dapat tercapai oleh mahasiswa. Direktorat Pembinaan SMK dalam Husna (2013) menyatakan materi atau isi modul harus sesuai dengan silabus.

d. Karakteristik modul yang dikembangkan memiliki karakteristik suatu pembelajaran berbasis problem based learning. Karakteristik modul pembelajaran berbasis problem based learning yang dimiliki adalah adanya masalah yang diberikan di awal materi. Hal ini sesuai dengan penelitian Savoie dalam Wena (2010: 91) bahwa modul Problem based learning yang diberikan tidak membuat asing dan familiar bagi mahasiswa. Modul juga mampu memunculkan soal bervariasi sehingga membuat mahasiswa termotivasi untuk belajar. Gambar yang terdapat dalam modul mampu membantu mahasiswa dalam memahami materi. Selain itu kreatifitas berpikir mahasiswa juga meningkat berkat adanya latihan di dalam modul. Contoh dan latihan yang diberikan sesuai dengan 
Pengembangan Modul Pembelajaran Kalkulus 1 Berbasis Problem Based Learning Di STMIK Duta Bangsa

Anisatul Farida, M.Pd., Ratna Puspita Indah, S.Si., M.Pd

masalah yang diberikan sehingga mampu meningkatkan kemampuan problem solving.

e. Terdapat kesesuaian antara tujuan dan materi perkuliahan, sehingga mahasiswa mencapai kompetensi yang diharapkan. Kesesuaian juga terdapat antara materi dan soal, serta kesesuaian contoh dengan latihan. Kesesuaian ini bermanfaat untuk mahasiswa sehingga mudah memahami materi dan contoh, serta dapat mengerjakan soal dengan baik.

f. Bahasa yang digunakan dalam modul berbasis PBL yakni berupa kalimat yang digunakan mudah dipahami dan sesuai dengan kaidah EYD. Struktur penggunaan kalimatnya juga sudah sesuai dengan kemampuan mahasiswa. Bahasa yang digunakan pun komunikatif. Hal ini sesuai dengan penyataan Direktorat Pembinaan SMK (2008:5) menyatakan bahwa modul haruslah menggunakan bahasa yang sederhana dan komunikatif. Kalimat yang mudah dipahami dan bahasa yang komunikatif membuat mahasiswa dapat memahami materi dalam modul tersebut.

g. Bentuk fisik modul berupa format dan desain isi modul menarik. Gambar yang digunakan dalam setiap kegitan belajar juga menarik dan terdapat hubungannya dengan materi. Selain itu, cover modul menarik dan mewakili isi modul secara keseluruhan. Isra (2008) memaparkan bahwa buku yang baik adalah buku yang disajikan secara menarik dilengkapi dengan gambar dan keteranganketerangannya. Bentuk fisik dari modul berbasis problem based learning yang menarik ini bertujuan meningkatkan motivasi dan semangat mahasiswa dalam mempelajari isi modul.

Tabel 1. Validasi modul

\begin{tabular}{|c|c|c|c|}
\hline No & Item & Pernyataan & Skor Validator \\
\hline \multirow{3}{*}{1.} & \multirow{3}{*}{ Tujuan } & a. Rumusan standar kompetensi jelas dan komprehensif & 3 \\
\hline & & $\begin{array}{l}\text { b. Jumlah standar kompetensi sesuai dengan waktu yang } \\
\text { tersedia }\end{array}$ & 4 \\
\hline & & Rata-rata Skor & 3,5 \\
\hline \multirow{4}{*}{2.} & \multirow{4}{*}{ Rasional } & a. Modul memiliki ciri khas & 3 \\
\hline & & b. Modul mampu memotivasi & 3 \\
\hline & & c. Modul bermanfaat untuk mahasiswa & 4 \\
\hline & & $\begin{array}{ll}\text { Rata-rata Skor } \\
\end{array}$ & 3,33 \\
\hline \multirow{4}{*}{3.} & \multirow{4}{*}{ Isi Modul } & a. Teori yang dipakai sesuai dengan materi & 4 \\
\hline & & b. Soal yang dipakai sesuai dengan materi & 3 \\
\hline & & c. Soal yang diberikan bervariasi & 3 \\
\hline & & Rata-rata Skor & 3,33 \\
\hline \multirow[t]{2}{*}{4.} & \multirow[t]{2}{*}{ Karakteristik } & a. Adanya masalah yang diberikan di awal materi & 4 \\
\hline & & b. Masalah yang diberikan familiar bagi mahasiswa & 3 \\
\hline
\end{tabular}




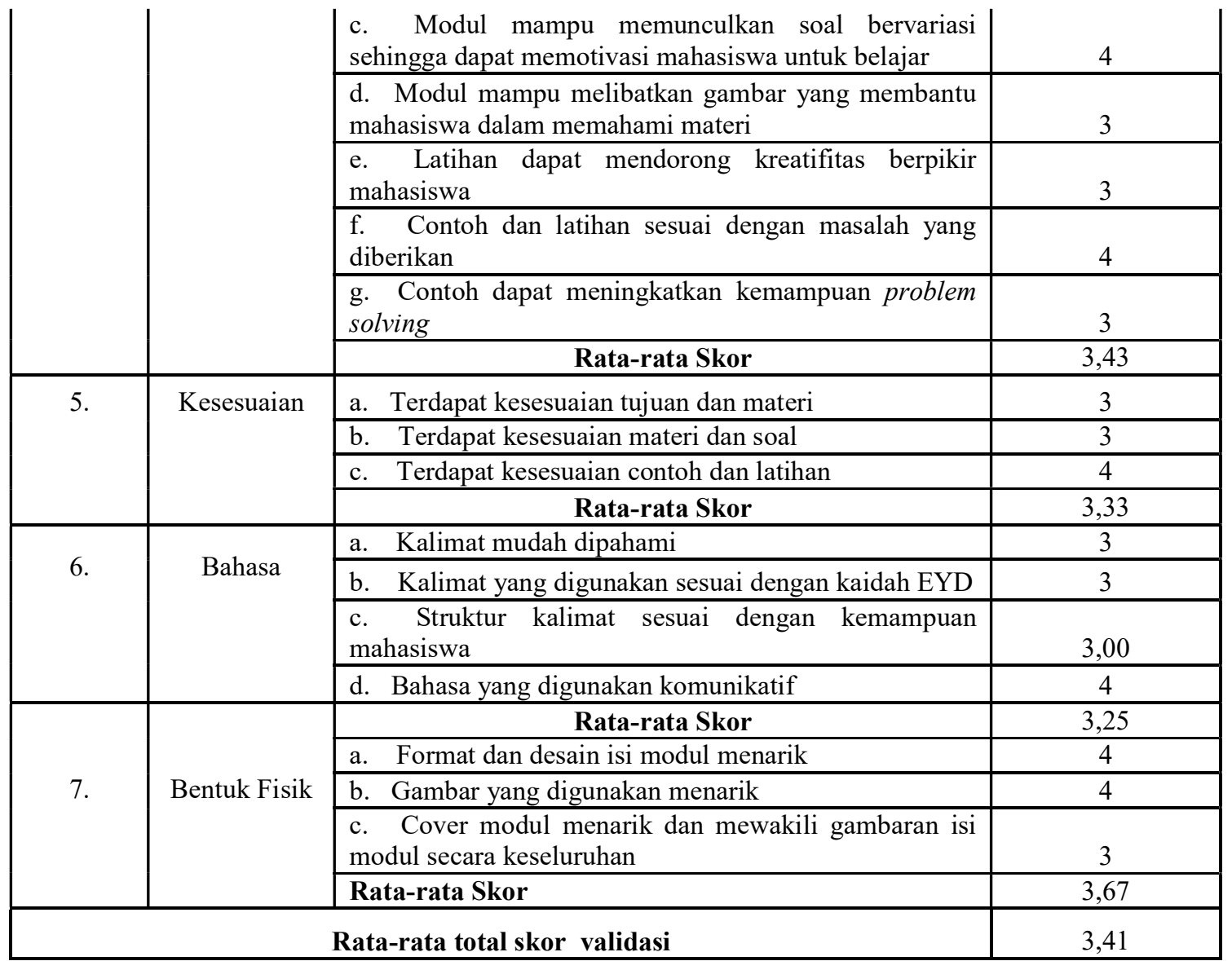

Dari kesimpulan di atas, dapat dikatakan bahwa modul berbasis masalah dinilai sudah memenuhi syarat sebagai bahan perkuliahan. Pada lembar validasi, validator juga memberikan catatan. Beberapa catatan validator diuraikan sebagai berikut.

a. Gambar menarik tetapi ada beberapa yang harus disesuaikan dengan topik masalah.

b. Gunakan bahasa yang baku dan sesuaikan dengan EYD

c. Kalimat/pernyataan harus jelas

d. Konsisten dalam menggunakan istilah.

e. Setiap rangkuman, harus jelas keterangannya. f. Berikan contoh yang menjadikan mahasiswa berpikir secara benar sesuai dengan tuntutan pemecahan masalah.

g. Pada latihan terbimbing lebih bagus kalau tidak diberikan tanda karena akan mengekang kreatifitas mahasiswa dalam menjawab soal yang diberikan.

Paul dan Purwanto (2005) juga menyatakan bahwa bahwa penulisan bahan ajar harus memperhatikan revisi dari validator sebelumnya untuk mendapatkan kualitas bahan ajar yang maksimal. 
Pengembangan Modul Pembelajaran Kalkulus 1 Berbasis Problem Based Learning Di STMIK Duta Bangsa

Anisatul Farida, M.Pd., Ratna Puspita Indah, S.Si., M.Pd

2. Praktikalitas Modul Berbasis Problem Based Learning

Untuk menjawab "Bagaimana praktikalitas modul berbasis problem based learning pada mata kuliah Kalkulus 1?" telah dilakukan observasi mengenai pelaksanaan perkuliahan dan wawancara dengan mahasiswa sehingga diperoleh kesi mpulan bahwa modul perkuliahan Kalkulus 1 sudah praktis. Hal-hal yang diamati selama observasi adalah sebagai berikut.

a. Observasi pelaksanaan perkuliahan dengan modul berbasis problem based learning.

Observasi pelaksanaan perkuliahan difokuskan untuk melihat apakah perkuliahan terlaksana dan melihat jika ada kendala dalam pelaksanaannya. Observasi dilakukan oleh satu orang observer. Uji praktikalitas ini dilakukan untuk mendapatkan informasi tentang keterpakaian modul berbasis masalah. Uji praktikalitas menjawab apakah modul berbasis masalah dapat digunakan atau tidak. Data praktikalitas modul berbasis masalah diperoleh dari observasi pelaksanaan perkuliahan dan wawancara dengan mahasiswa.

Modul ini berisi 2 kegiatan belajar (limit dan fungsi kontinue serta turunan).

1. Kegiatan belajar 1 dipelajari selama 2 pertemuan mengenai limit dan fungsi kontinue. Pada awal pertemuan ini, mahasiswa tampak enggan untuk belajar dengan menggunakan modul. Hal ini disebabkan mahasiswa sudah terbiasa dengan mendengarkan penjelasan materi dari dosen. Dengan adanya arahan dari dosen, hal ini dapat diatasi. Mahasiswa diminta mempelajari terlebih dahulu materi dan contoh soal secara mandiri. Apabila ada kendala, maka mahasiswa tersebut boleh bertanya kepada dosen. Semua latihan terbimbing bisa diselesaikan ketika perkuliahan. Dosen meminta mahasiswa mengerjakan latihan mandiri yang belum dibahas supaya diselesaikan di luar perkuliahan. Tidak ada kendala berarti yang ditemui selama perkuliahan

2. Kegiatan belajar 2 tentang turunan fungsi. Mahasiswa sudah mulai terbiasa belajar mandiri tanpa bantuan sepenuhnya dari dosen. Namun, pada latihan terbimbing tentang turunan fungsi masih ada yang bertanya kepada dosen. Pada kegiatan belajar ini, tidak ada kendala yang ditemui selama perkuliahan. Selain mempelajari materi pada kegiatan 2, pertemuan ini juga membahas soal yang tidak dapat diselesaikan oleh mahasiswa di rumah. Materi pada kegiatan 2 agak sulit dari materi sebelumnya, hal ini menyebabkan ada soal pada latihan terbimbing yang tidak terjawab.Sehingga latihan 
terbimbing dikerjakan bersama dengan arahan dari dosen. Tugas mandiri dijadikan tugas di rumah.

Berdasarkan hasil pengamatan yang dituangkan observer dalam lembar observasi diperoleh keterangan bahwa penggunaan modul Kalkulus 1 dapat dikatakan praktis. Selama proses pembelajaran terlihat tidak terdapat permasalahan yang berarti. Mahasiswa mudah menggunakan modul Kalkulus 1. Ini terlihat dari sedikit mahasiswa yang bertanya mengenai isi dan format modul karena di awal,modul sudah ditampilkan petunjuk penggunaan . Rata-rata kesulitan yang mereka peroleh adalah dalam menyelesaikan/memahami soal latihan yang diberikan. Namun demikian sebagian besar mahasiswa dapat menyelesaikan/mempelajari modul untuk setiap pertemuan.

b. wawancara dengan mahasiswa mengenai praktikalitas modul berbasis problem based learning

Hasil wawancara dengan mahasiswa mengenai praktikalitas modul berbasis masalah. Wawancara dilakukan kepada mahasiswa yang sedang mengambil mata kuliah Kalkulus 1. Waktu yang digunakan untuk wawancara adalah setelah mahasiswa selesai mengikuti perkuliahan dengan menggunakan modul. Indikator yang digunakan dalam wawancara ini adalah waktu, penggunaan, dan manfaat. Berikut uraian hasil wawancara dengan mahasiswa tersebut.

1. Waktu cukup tersedia untuk mahasiswa memahami materi. Mahasiswa berpendapat bahwa waktu yang tersedia cukup jika mereka mempelajari dengan baik. Waktu yang dibutuhkan untuk memahami materi bagi sebagian mahasiswa terasa lebih singkat jika terlebih dahulu belajar secara mandiri.

2. Soal-soal yang terdapat dalam modul bervariasi berdasarkan tingkat kesulitan. Ada soal yang tergolong mudah, sedang, dan sukar. Hal ini mengakibatkan sebahagian mahasiswa belum dapat menyelesaikan semua soal yang diberikan. Mahasiswa masih membutuhkan bantuan dosen untuk menyelesaikan soal yang tergolong sukar.

3. Mahasiswa dapat memahami bahasa dalam penyajian materi. Gambar yang ditampilkan membantu mahasiswa dalam memahami konsep. Bahasa yang komunikatif dan gambar yang cukup menarik membuat mahasiswa mudah memahami materi.

4. Manfaat yang diperoleh dari belajar dengan modul berbasis masalah diantaranya adalah dapat meningkatkan motivasi belajar mahasiswa dan memberikan kesempatan kepada mahasiswa untuk belajar secara mandiri. 
Pengembangan Modul Pembelajaran Kalkulus 1 Berbasis Problem Based Learning Di STMIK Duta Bangsa

Anisatul Farida, M.Pd., Ratna Puspita Indah, S.Si., M.Pd

Berdasarkan hasil wawancara dengan mahasiswa di atas dapat disimpulkan bahwa modul berbasis masalah pada perkuliahan Kalkulus 1 sudah praktis baik dari segi isi maupun waktu penggunaannya. Ini sesuai dengan penelitian Husna, Anny Sovia, dkk (2013) yang menyatakan bahwa kualitas modul dapat dikatakan praktis apabila mudah dalam penggunaan serta efektif waktu penggunaannya. Namun, sebagian mahasiswa masih terkendala untuk soal latihan mandiri dengan tingkat kesukaran tinggi. Oleh sebab itu, mahasiswa dituntut untuk rajin mengerjakan latihan agar terbiasa dengan jenis soal yang bervariasi dan dengan tingkat kesukaran yang berbeda.

\section{Efektifitas Modul Berbasis Problem Based Learning}

Untuk menjawab pertanyaan "Bagaimanakah efektivitas dari modul pada perkuliahan Kalkulus 1 berbasis problem based learning di STMIK Duta Bangsa?", maka telah dilakukan deskripsi dan analisis data tentang aktivitas dan hasil belajar mahasiswa. Berdasarkan hasil analisis data pengamatan aktivitas mahasiswa selama perkuliahan menunjukkan bahwa perkuliahan dengan menggunakan modul telah mendorong meningkatnya aktivitas belajar mahasiswa. Hal ini sesuai dengan penelitian Rahima (2015) yang menyatakan bahwa efektivitas modul dapat dilihat dari aktivitas belajar mahasiswa. Aspek efektivitas dapat dinilai apabila produk tersebut sudah valid dan praktis.

a. Aktivitas mahasiswa

Berdasarkan hasil observasi aktivitas mahasiswa selama perkuliahan menunjukkan bahwa modul pada perkuliahan Kalkulus 1 dapat memunculkan aktivitas positif dan mengurangi aktivitas negatif mahasiswa. Aktivitas yang banyak sekali muncul dan sangat berhasil dilaksanakan di kelas adalah visual activities (membaca modul) dan writing activities (mengerjakan latihan). Membaca modul akan membantu mahasiswa dalam memahami materi dan mengerjakan latihan dapat menguji sejauh mana pemahaman mahasiswa terhadap materi yang telah dibaca tersebut.

Aktivitas lainnya yang banyak muncul dan berhasil dilaksanakan adalah drawing activities (menggambar atau membuat sketsa) dan mental activities (menanggapi, menganalisis, melihat hubungan dan menyimpulkan pembelajaran). Mahasiswa membuat gambar atau sketsa grafik ketika melakukan penemuan konsep dan menyelesaikan latihan.

Aktivitas negatif yakni oral activities dan motor activities digolongkan tidak berhasil muncul di dalam kelas karena persentasenya sedikit sekali. Hal ini disebabkan karena modul telah disajikan secara jelas sehingga 
mahasiswa dapat memahaminya. Secara umum, perkuliahan dengan menggunakan modul dapat meminimalkan munculnya aktivitas negatif.

\section{b. Hasil belajar mahasiswa}

Hasil belajar mahasiswa yang diperoleh melalui tes akhir menunjukkan bahwa ratarata hasil belajar sudah baik namun ada beberapa mahasiswa mengalami penurunan. Salah satu penyebab terjadinya penurunan tersebut adalah sifat dari tingkat kesulitan materi. Tingkat kesulitan materi selalu berkembang pada setiap pertemuan. Penyebab lainnya adalah mahasiswa cenderung tidak cermat dalam mengerjakan limit dan turunan. Meskipun konsep Kalkulus 1 sudah dipahami namun ketidakcermatan mahasiswa dalam menyelesaikan soal sangat berpengaruh terhadap penilaian.

Hasil belajar mahasiswa yang diperoleh melalui tes menunjukkan bahwa lebih dari $70 \%$ mahasiswa memperoleh nilai yang berkisar antara 65-100. Ini menunjukkan bahwa penggunaan modul berbasis problem based learning pada mata kuliah Kalkulus 1 mampu meningkatkan hasil belajar mahasiswa. Hasil belajar yang meningkat menunjukkan modul yang efektif (Rahima, 2015). Perlu beberapa perbaikan pada modul untuk penelitian selanjutnya agar menghasilkan modul yang berkualitas dan membantu kemandirian belajar mahasiswa

\section{KESIMPULAN}

Berdasarkan hasil penelitian, diperoleh kesimpulan bahwa modul berbasis PBL pada perkuliahan Kalkulus 1 memiliki validitas yang sangat valid baik dari aspek konstruk dan isi. Praktikalitas modul diperoleh melalui observasi pada pelaksanaan perkuliahan dan hasil wawancara diperoleh hasil bahwa modul pada perkuliahan Kalkulus 1 sudah praktis dan mudah digunakan oleh mahasiswa dari segi waktu. Efektivitas modul pada perkuliahan Kalkulus 1 sudah efektif berdasarkan hasil belajar dan pengamatan aktivitas mahasiswa.

Hasil penelitian ini menunjukkan bahwa perkuliahan dengan menggunakan modul yang dikembangkan pada penelitian ini dapat meningkatkan aktivitas dan hasil belajar mahasiswa. Oleh karena itu, modul dapat dijadikan salah satu alternatif bahan perkuliahan bagi dosen dan mahasiswa.

Modul ini dapat dijadikan contoh bagi dosen dalam mengembangkan modul yang lain. Perbaikan dan modifikasi dapat dilakukan dengan tetap memperhatikan prosedur penelitian. Berdasarkan penelitian pengembangan modul ini, peneliti memiliki beberapa saran yakni uji coba modul ini masih sangat terbatas yaitu terhadap satu kelas saja dan materi yang diujicobakan hanya satu modul saja berisi dua kegiatan belajar. Sebaiknya, dosen mengujicobakan pada kelas lain yang paralel dengan materi uji 
Pengembangan Modul Pembelajaran Kalkulus 1 Berbasis Problem Based Learning Di STMIK Duta Bangsa

Anisatul Farida, M.Pd., Ratna Puspita Indah, S.Si., M.Pd

coba yang lebih banyak sehingga dapat meminimalisir berbagai kekurangan pada modul

Kepada pihak lain yang ingin melanjutkan penelitian atau memakai modul ini, disarankan untuk menambahkan strategi tertentu dalam proses pembelajaran sehingga bisa diperoleh hasil yang maksimaldari segi hasil belajar dan kemandirian belajar mahasiswa. Penelitian pengembangan akan lebih sempurna jika dilakukan sampai tahap keempat (disseminate atau penyebaran). Ucapan terima kasih kami sampaikan kepada KemenristekDikti yang telah mendanai dalam pelaksanaan penelitian ini.

\section{REFERENSI}

Dimyati dan Mudjiono. 2006. Belajar dan Pembelajaran. Jakarta: PT. Rineka Cipta

Depdiknas. 2006. Pengembangan Bahan Ajar. www.jardiknas.org

Husna, Anny S, dkk. 2013. Praktikalitas Modul Berbasis Masalah pada Perkuliahan Kalkulus 1 di STKIP Sumatera Barat.

Isra, Nurmaiyenti. 2008. "Pengembangan Buku Kerja Berbasis Konstruktivisme Pada Perkuliahan Kalkulus 1 Di Stain Batusangkar". Tesis tidak diterbitkan. Padang: Program Pasca Sarjana UNP.

Lufri. 2008. Penelitian Tindakan Kelas dan Penelitian Pengembangan. Padang: FMIPA UNP
Paulina dan Purwanto. 2005. Penulisan Bahan ajar. Jakarta: PAU PPAI-UT

Permenristek Dikti No. 44 Tahun 2015

Rahima. 2015. Efektivitas Modul Berbasis Masalah pada Perkuliahan KPB 2 terhadap Aktivitas Mahasiswa di STKIP Sumatera Barat. Jurnal Lemma, Vol II No. 1, November 2015.

Rudi Chandra. 2010.”Pengembangan modul pemrograman pascal untuk mahasiswa program studi pendidikan matematika STKIP PGRI SUMBAR". Tesis tidak diterbitkan. Padang: Program Pasca Sarjana UNP.

Sugiyono, 2008. Metode Penelitian Pendidikan. Bandung: CV. Alfabeta

Suprawoto. 2009. Mengembangkan Bahan Ajar dengan Menyusun Modul. (http://www.scribd.com/doc/16554502/ Mengembangkan-Bahan-Ajar-denganMenyusun-Modul, diakses 20 September 2010)

Trianto. 2007. Model Pembelajaran Terpadu dalam Teori dan Praktek. Jakarta: Prestasi Pustaka

Wena, Made. 2010. Strategi Pengembangan Inovatif Kontemporer. Jakarta: Bumi Aksara 